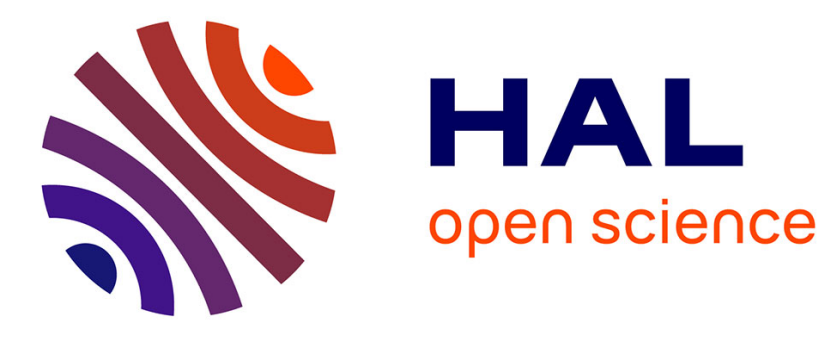

\title{
Damages and cracks in ceramic/metal interfaces
}

\author{
Daniel Juvé, P. Lourdin, B. Mbongo, N. Boukheit, D. Treheux
}

\section{To cite this version:}

Daniel Juvé, P. Lourdin, B. Mbongo, N. Boukheit, D. Treheux. Damages and cracks in ceramic/metal interfaces. Journal de Physique IV Proceedings, 1993, 03 (C7), pp.C7-1057-C7-1060. 10.1051/jp4:19937164. jpa-00251788

\section{HAL Id: jpa-00251788 https://hal.science/jpa-00251788}

Submitted on 1 Jan 1993

HAL is a multi-disciplinary open access archive for the deposit and dissemination of scientific research documents, whether they are published or not. The documents may come from teaching and research institutions in France or abroad, or from public or private research centers.
L'archive ouverte pluridisciplinaire HAL, est destinée au dépôt et à la diffusion de documents scientifiques de niveau recherche, publiés ou non, émanant des établissements d'enseignement et de recherche français ou étrangers, des laboratoires publics ou privés. 


\title{
Damages and cracks in ceramic/metal interfaces
}

\author{
D. JUVE, P. LOURDIN, B. MBONGO, N. BOUKHEIT and D. TREHEUX \\ Laboratoire Matériaux-Mécanique Physique, URA 447 du CNRS, Ecole Centrale de Lyon, BP. 163, \\ 69131 Ecully cedex, France
}

\begin{abstract}
:
When metal/ceramic junctions are achieved by solid state bonding process, damages and cracks are often observed near by the interface. This paper focuses on the mechanical origin of the embrittlement. The main causes are:

- residual stresses due to the mismatch in the mechanical properties of the materials to be joined

- friction of metal on the ceramic surface at the interface during bonding

- decrease of the toughness of the ceramic close to the interface consecutively to the diffusion of the metallic specie into the ceramic.
\end{abstract}

\section{THERMAL RESIDUAL STRESSES:}

The localization of tensile and compressive stresses in the case of a solid state bonded $\mathrm{Ni} / \mathrm{Al}_{2} \mathrm{O}_{3}$ system [1] has been investigated using numerical simulations (finite element -Sysweld soft from Framasoft Lyon). To simulate cooling, a decrease in temperature from $1200^{\circ} \mathrm{C}$ to $20^{\circ} \mathrm{C}$ is imposed on the bond. To avoid the effect of a thermal gradient, at each step of time a uniform temperature is also imposed at every node of the mesh. Mechanical calculations take into account:

- the mismatch in thermal expansion coefficient between nickel and alumina.

- the evolution of the mechanical characteristics of the two materials with temperature.

Figure 1 shows the mesh used to conduct the calculation and the resulting stress fields.

$-\sigma_{x x}$ tensile stresses are located in nickel and tend to decrease near the edge of the bond. According to their intensity and localization they probably do not affect the mechanical strength of the bond.

- shear stresses $\left(\sigma_{x y}\right)$ are weak and maximum in an area located near by the interface, at the edge of the bond.

- $\sigma$ yy stresses exhibit a high tensile zone in the alumina at $0,1 \mathrm{~mm}$ far from the interface. This layer can induce brittle fracture into ceramic.

\section{EDGE FLAWS:}

To obtain a maximum bond strength, metal and ceramic have to be solid state bonded under a pressure leading to the maximum contact area between both materials [2]. Nevertheless, if the bonding conditions (particularly temperature and pressure) induce an overflowing of the metal out of contact, flaws are observed near by the edge of the junction.

Althrough the pressure is initally uniformly applied on the sample, if the yield strength of the metal is exceeded during bonding, the friction of the metal on the ceramic surface induces interfacial shear stresses. Then a modification of the repartition of the applied pressure in the metal is effective. In this case it has been shown that [3-5]:

- compressive stresses diminish from the center of the junction to the periphery

- shear stresses are zero at the center and increase to the periphery. 
High shear stresses associated to weak compressive stresses at the edge of the junction lead to an interfacial shearing at the periphery of the junction and then defects are created. In the case of $\mathrm{Ni} / \mathrm{Al}_{2} \mathrm{O}_{3}$ different kinds of defects have been observed ( figure 2):

- the first one appears at very high bonding temperature $\left(1400^{\circ} \mathrm{C}\right)$ because of the small yield strength of the metal. Sliding on the asperities of the ceramic surface the metal is scratched (figure $2 \mathrm{a}$ ). Furthermore, nickel grain boundaries appears to be locally thermal etched, indicating the presence of unbonded areas.

- the second one is observed for medium temperatures, metal being harder, it damages the ceramic surface by friction. Figure $2 b$ shows that alumina grains has been detached, probably because of flaws that preexist in the ceramic and then remain embedded into metal.

- the third one is observed at temperatures lower than $1250^{\circ} \mathrm{C}$ and for applied pressures higher than $20 \mathrm{MPa}$. The metal has retained high yield strength. Sliding and going out of the contact zone it induces damages in ceramic by cracking and detaching "chips" outside the bonding area (figure $2 \mathrm{c}$ ).

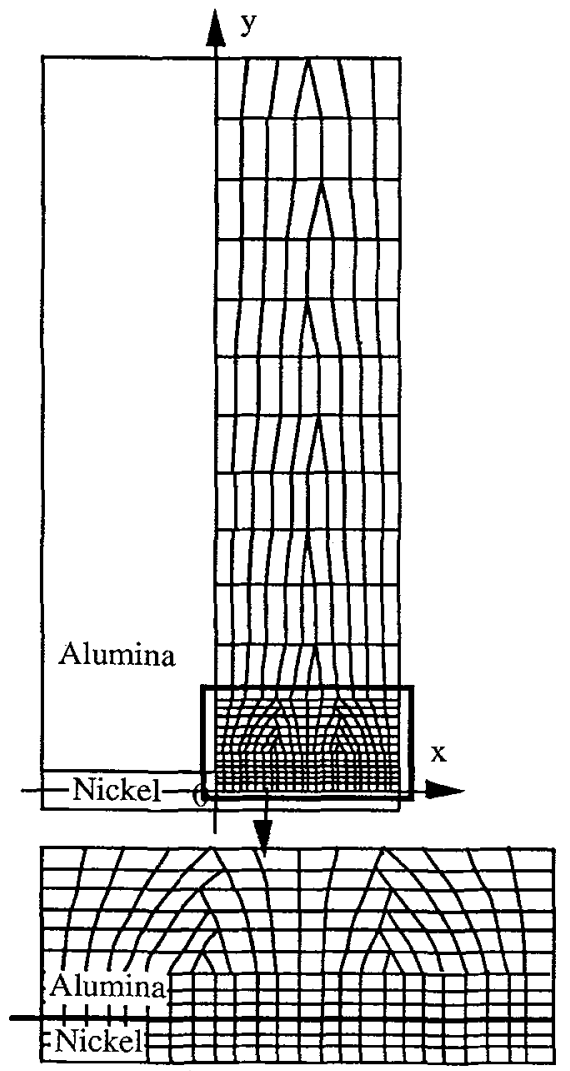

area shown on stress map

a/

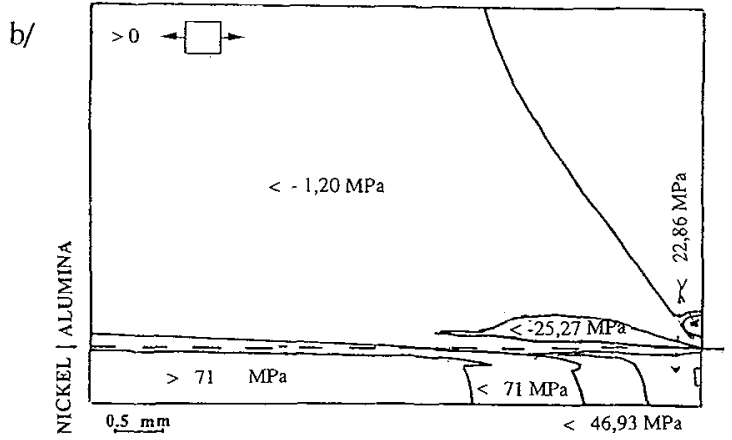

c)

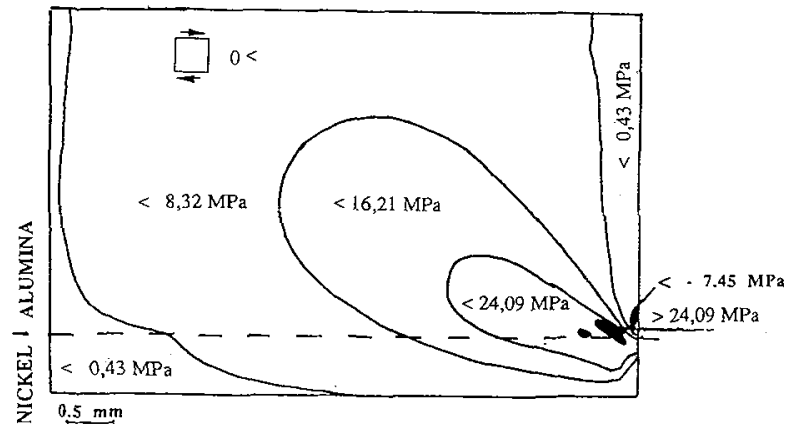

d/

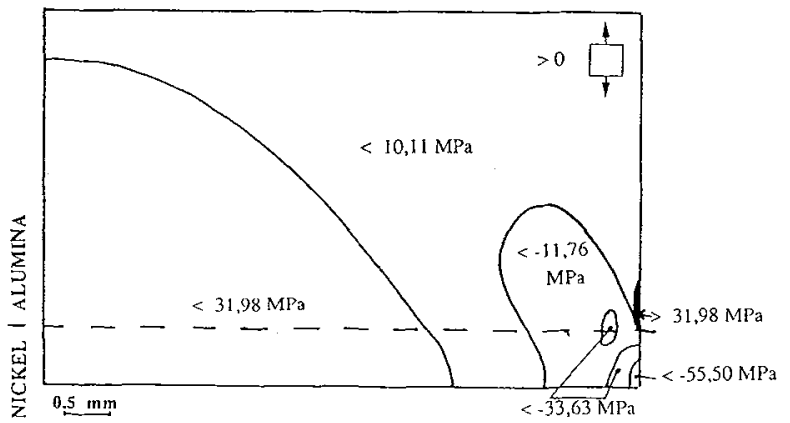

Figure 1: Maps of the residual thermal stresses fields near the $\mathrm{Ni} / \mathrm{Al}_{2} \mathrm{O}_{3}$ interface. a/ Finite element mesh . $\mathrm{b} / \sigma_{\mathrm{xx}}$ : stresses parallel to the interface. $\mathrm{c} / \sigma_{\mathrm{xy}}$ : shear stresses. $\mathrm{d} / \sigma_{\mathrm{yy}}$ : stresses perpendicular to the interface 


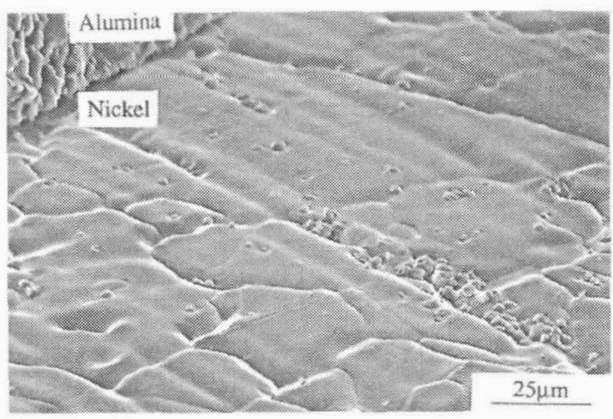

al

b/

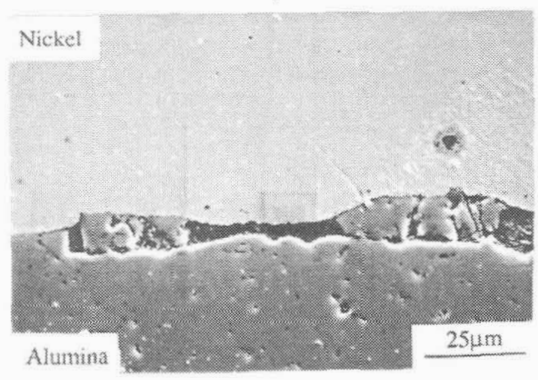

c)

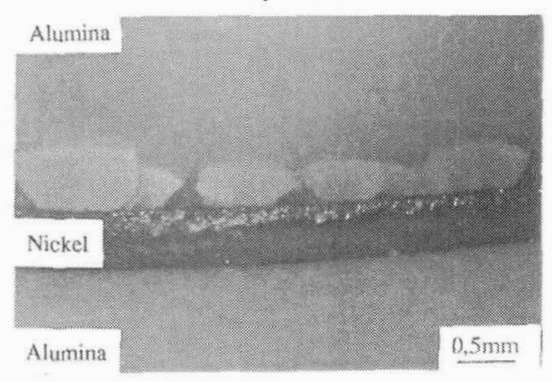

Figure 2: Flaws at the edge of a $\mathrm{Ni} / \mathrm{Al}_{2} \mathrm{O}_{3}$ interface. a/ scratches on nickel surface. $\mathrm{b} /$ alumina grains detached by nickel. c/ external "chipping" of alumina.

\section{CERAMIC TOUGHNESS NEAR BY THE INTERFACE:}

Several alumina/metal specimens were solid state bonded using conditions leading to highest tensile fracture strength as measured by the push-test method $(1,2,6)$. Samples were cut perpendicularly to the interface, then polished. Vickers indentations (applied load $10 \mathrm{~N}$ ) were performed in alumina from the metal-ceramic interface to the ceramic bulk. Fracture toughness was calculated from the Liang et al formula [7].

Figure 3 shows a decrease in the ceramic toughness near the interface. $K_{I C}$ drops from $7 \mathrm{MPa} / \mathrm{m}$ in the bulk to about $4 \mathrm{MPa} \sqrt{\mathrm{m}}$ at $50 \mu \mathrm{m}$ from the interface whatever the metal bonded (Cu, $\mathrm{Pt}, \mathrm{Ni})$.

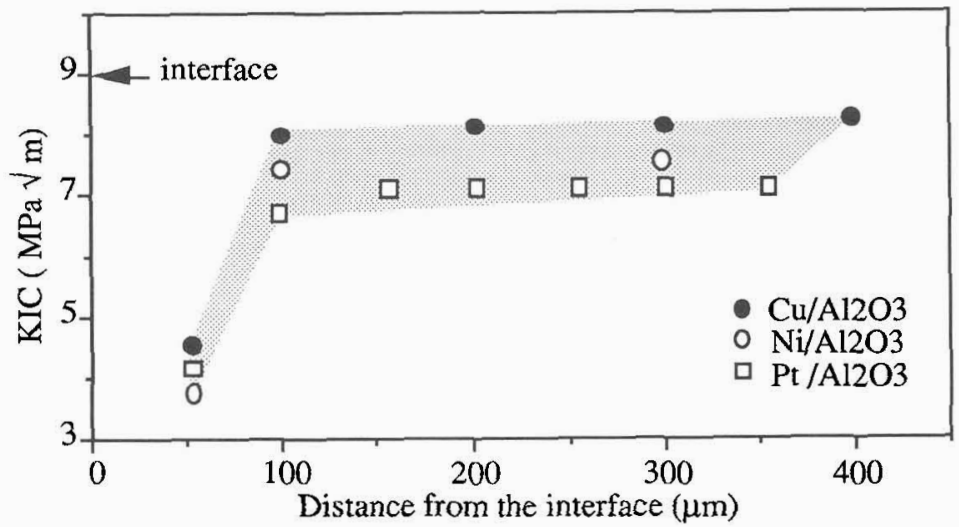

Figure 3: Alumina toughness vs distance from the interface for several metal/alumina bonds. 
A previous study $(6,8)$ showed that, for $\mathrm{Ag} / \mathrm{Al}_{2} \mathrm{O}_{3}$, optimal bonding ( tensile strength $70 \mathrm{MPa}$ ) is obtained, at $900^{\circ} \mathrm{C}$ in air, either using annealed silver, for 4 hours bonding time, either using cold rolled (80\%) silver without any plateau at $900^{\circ} \mathrm{C}$. The decrease in toughness is only observed for long bonding time (annealed $\mathrm{Ag}$ ) as shown on figure 4 . This decrease has to be related to residual stresses and diffusion of metallic specie, particularly along grain boundaries, as demonstrated previously $(8,9)$.

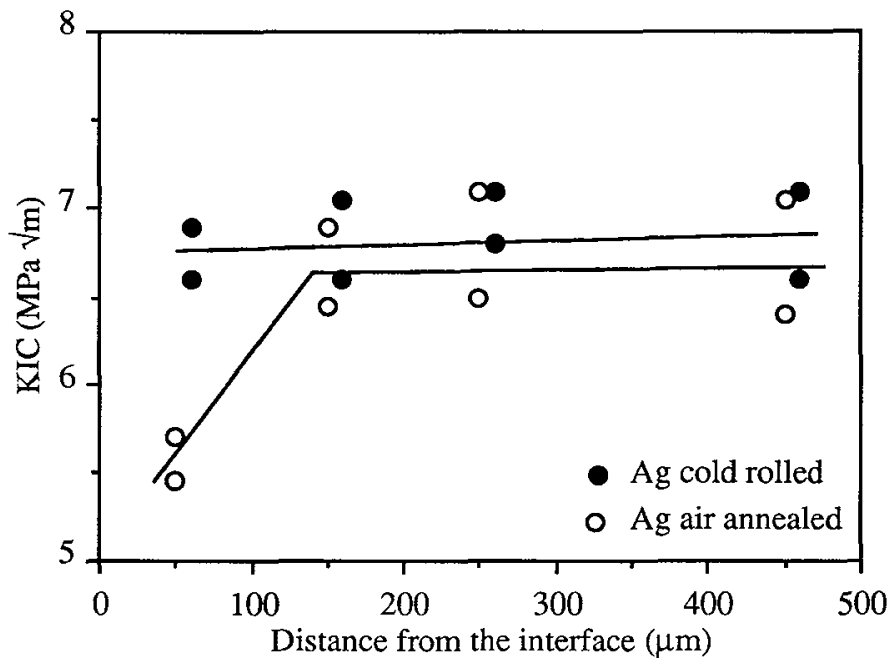

Figure 4: $\mathrm{Ag} / \mathrm{Al}_{2} \mathrm{O}_{3}$ system. Alumina toughness after bonding.

\section{CONCLUSION:}

The association of high residual stresses in the ceramic, at the edge of the junction, and of defects, acting as notches, located in the same area, limit the fracture strength of metal/ceramic bonds. To avoid such embrittlement, bonding pressure has to be chosen to induce highest contact area without flaws or unbonded zones. In addition, alumina seems to be embrittled because of diffusion of metallic specie even for non reactive systems.

\section{REFERENCES:}

[1] Lourdin P., Thesis N92-31 Ecole Centrale de Lyon (1992)

[2] Courbière M., Thesis No86- Ecole Centrale de Lyon (1986)

[3] Avitzur B., Int. J .Mach. Tool Des.Res 9 (1969) 165

[4] Gent A.N., Henry R.L., Roxbury M.L., J. of Appl. Mech. .12 (1974) 855.

[5] Gupta G.D., J. of Appl.Mech. 3 (1975) 81.

[6] Serier B., Tréheux D., Acta Metall. Mater. 41 n² (1993) 369.

[7] Liang K.H., Orange G., Fantozzi G., Journal of Material Science 25 (1990) 207

[8] Serier B., Thesis $N^{\circ}$ 91-19 Ecole Centrale de Lyon (1991)

[9] Serier B., Berroug A., Juvé D., Tréheux D., Moya E.G., J. European Ceram. Soc. (to be published) 